ARTICLES

\title{
Distinguishing between Rooted and Rootless Detachments: A Case Study from the Mormon Mountains of Southeastern Nevada
}

\author{
Mark H. Anders, Nicholas Christie-Blick, and Christopher D. Walker \\ Department of Earth and Environmental Sciences and Lamont-Doherty Earth Observatory of Columbia \\ University, Palisades, New York 10964, U.S.A. \\ (e-mail: manders@ldeo.columbia.edu)
}

\begin{abstract}
A B S T R A C T
Rooted detachment faults and detachments beneath rootless slide blocks exhibit many similar structural characteristics. However, while rooted detachments are thought to penetrate into the midcrust and to accommodate significant crustal extension, rootless detachments break to the surface downdip and are not directly involved in such extension. Distinguishing between these two mechanically different kinds of structure is central to the assessment of extension magnitude. Here we examine deformation along the Mormon Peak detachment, a feature that has been cited as an example of both a rooted and a rootless structure. Located in the Mormon Mountains of southeastern Nevada, this detachment has been interpreted as one of three low-angle normal faults of regional scale that together are thought to have accommodated more than $50 \mathrm{~km}$ of Basin and Range extension. For the most part, however, the Mormon Peak detachment is expressed as a series of isolated exposures where Paleozoic rocks are in brittle fault contact with nonmylonitized underlying rocks. Individual blocks contain high-angle normal faults that terminate downward at their respective detachment surfaces, yielding a geometry common to both modes of emplacement. In order to test between these competing interpretations, we studied deformational characteristics close to the detachment surface, reasoning that a seismogenic fault ought to differ fundamentally from a surficial slide block, particularly if the slide block was emplaced in a single event rather than by protracted or episodic creep. An examination of the contact mapped as the Mormon Peak detachment reveals that the character of deformation is indistinguishable from that of known gravity-driven slide blocks and is fundamentally different from that associated with seismically cycled faults. Moreover, the orientation of kinematic indicators observed at detachment surfaces is consistently close to the downdip direction, which in many places diverges strongly from the expected direction of movement in the rooted detachment model. We conclude that outcrops of the inferred upper plate of the Mormon Peak detachment represent an assemblage of individual rootless gravity-driven slide blocks and not the erosional remnants of a formerly contiguous extensional allochthon. If similar misidentifications have been made elsewhere in the Basin and Range Province, total Cenozoic extension may have been significantly overestimated. Implications for the interpretation of extensional geology in general are far-reaching.
\end{abstract}

\section{Introduction}

Fundamental theory for the behavior of materials under stress suggests that normal faults within the brittle field should lock up at dip angles of less than about $20^{\circ}$ (e.g., Sibson 1985; Collettini and Sibson 2001; Scholz 2002). No available earthquake evidence unequivocally contradicts this expectation (Jackson and White 1989; cf. Abers 1991; Rietbrock 2006.

Manuscript received August 23, 2005; accepted June 26,

et al. 1996; Abers et al. 1997). Many field geologists nevertheless regard outcrop evidence for active upper crustal low-angle normal faults rooting into ductile substrates as "overwhelming" (e.g., Wernicke 1995; Axen 1999, 2004).

It is clear that, under certain circumstances, normal slip is possible in the brittle field on surfaces inclined at as little as a fraction of a degree. Examples include salt collapse structures and gravitydriven slides (see Yarnold and Lombard 1989; Jack-

[The Journal of Geology, 2006, volume 114, p. 645-664] @ 2006 by The University of Chicago. All rights reserved. 0022-1376/2006/11406-0001\$15.00 
son et al. 1995). Conditions necessary for such deformation include an extremely low coefficient of basal friction and/or a setting in which topography leads to deflection of the maximum principal stress toward the horizontal (see Shaller 1991).

Landslides and slide blocks are commonly associated with mountain building in both contractional and extensional settings (e.g., Armstrong 1972), and in some cases they are distinguished with difficulty from the purported effects of extensional detachment faulting (e.g., Boyer and Allison 1987). This is reflected in the use of similar nomenclature. The term "detachment" is adopted in both cases for the sharp, planar to broadly undulating basal discontinuity, and where a detachment reaches Earth's surface up dip, the fault is called a "breakaway" (see Pierce 1980; Wernicke 1995). In both cases, allochthonous rocks are disrupted by abundant high-angle normal faults that sole into or terminate against the detachment surface.

A clear distinction between these phenomena is possible when a toe is present. A toe is the portion of a gravity-driven slide associated with propagation of a detachment toward the Earth's surface in the direction of displacement. In many and perhaps most cases, however, slide toes are partially or completely buried by younger sediments (e.g., Philip and Ritz 1999). Beutner (1968, 1972), Moores (1968), Moores et al. (1968, Moore et al. (1987), Anders (1990), Morris and Hebertson (1996), and Wills and Anders (1999) all described slide blocks that originated in the footwall of a range-bounding normal fault and that are now partially buried within an actively subsiding hanging-wall basin. In the case of the Horse Creek and South Creek slide blocks in central Idaho (Beutner 1968, 1972), the edges of toes are sufficiently obscured by younger sediments that the blocks were originally interpreted as bedrock (Anderson 1948; Ross 1961). Slide blocks partially buried by sediments in the Canyon Range of west-central Utah were similarly mapped as bedrock because a basal surface was not initially recognized. Indeed, it was the discovery of a basal detachment atop Cenozoic gravels that led to a reevaluation of field relations (see Morris and Hebertson 1996; Wills and Anders 1999).

In the absence of outcrop evidence for a toe or of seismic reflection, borehole, or other geophysical data, criteria are needed to distinguish between these two very different interpretations. In this article, we make the case that the character of deformation associated with surficial slide blocks differs markedly from that of a seismically cycled normal fault and that such differences provide the sought-after criteria. Reinterpretation of the Mor- mon Peak detachment, a well-known example of an inferred rooted low-angle normal fault in the Mormon Mountains, Nevada (fig. 1), as a product of surficial sliding suggests that other similar structures may have been misinterpreted as rooted, thereby resulting in overestimates of regional extension.

\section{Gravity-Driven Slide Blocks}

Gravity-driven mass displacement phenomena are known to vary greatly in scale, emplacement rate, and degree of internal disruption of transported materials (see Voight and Pariseau 1978). Among the most impressive are rock avalanches, catastrophic mass failures accompanied by total disaggregation and fluidization of the rocks involved (e.g., Yarnold and Lombard 1989; Shaller 1991). In this article, we are concerned with rapidly emplaced slide blocks that, while associated with intense deformation in proximity to the detachment and with disruption by subsidiary faults, maintain a coherent internal stratigraphy (e.g., the Heart Mountain detachment; Pierce 1957; Hauge 1993). Counterintuitively, given the profound contrast in emplacement mechanism, it is slide masses of this kind that are most easily misinterpreted as rooted.

A unique characteristic of many large slide blocks is the presence at their base of a discontinuous but widespread layer of conglomerate (Yarnold and Lombard 1989; Shaller 1991; Boyer and Hossack 1992; Yarnold 1993; Morris and Hebertson 1996; Beutner and Gerbi 2005). The conglomerate, which is texturally similar to concrete (for photomicrographs and descriptions, see Yarnold and Lombard 1989; Shaller 1991), commonly banded, and characterized in places by both normal and reverse grading (Anders et al. 2000), was clearly involved in slide block emplacement. Networks of clastic dikes, which in many gravity slide masses extend as much as tens of meters above the detachment, are typically filled by conglomerate lithologically indistinguishable from that of the basal zone (Krieger 1977; Yarnold and Lombard 1989; Shaller 1991; Boyer and Hossack 1992; Friedmann 1997). Other comparable attributes include breccia clasts, flow banding, internal erosion surfaces, and grading perpendicular to dike walls (Peterson 1968; Yarnold and Lombard 1989; Schmitt 1991; Malone et al. 1999). Clastic dikes are rarely, if ever, found injected into rock below the detachment surface of a slide block (e.g., Pierce 1979; Shaller 1991; Malone et al. 1999).

Together, these features are thought to result from the fluidization of granular material during 

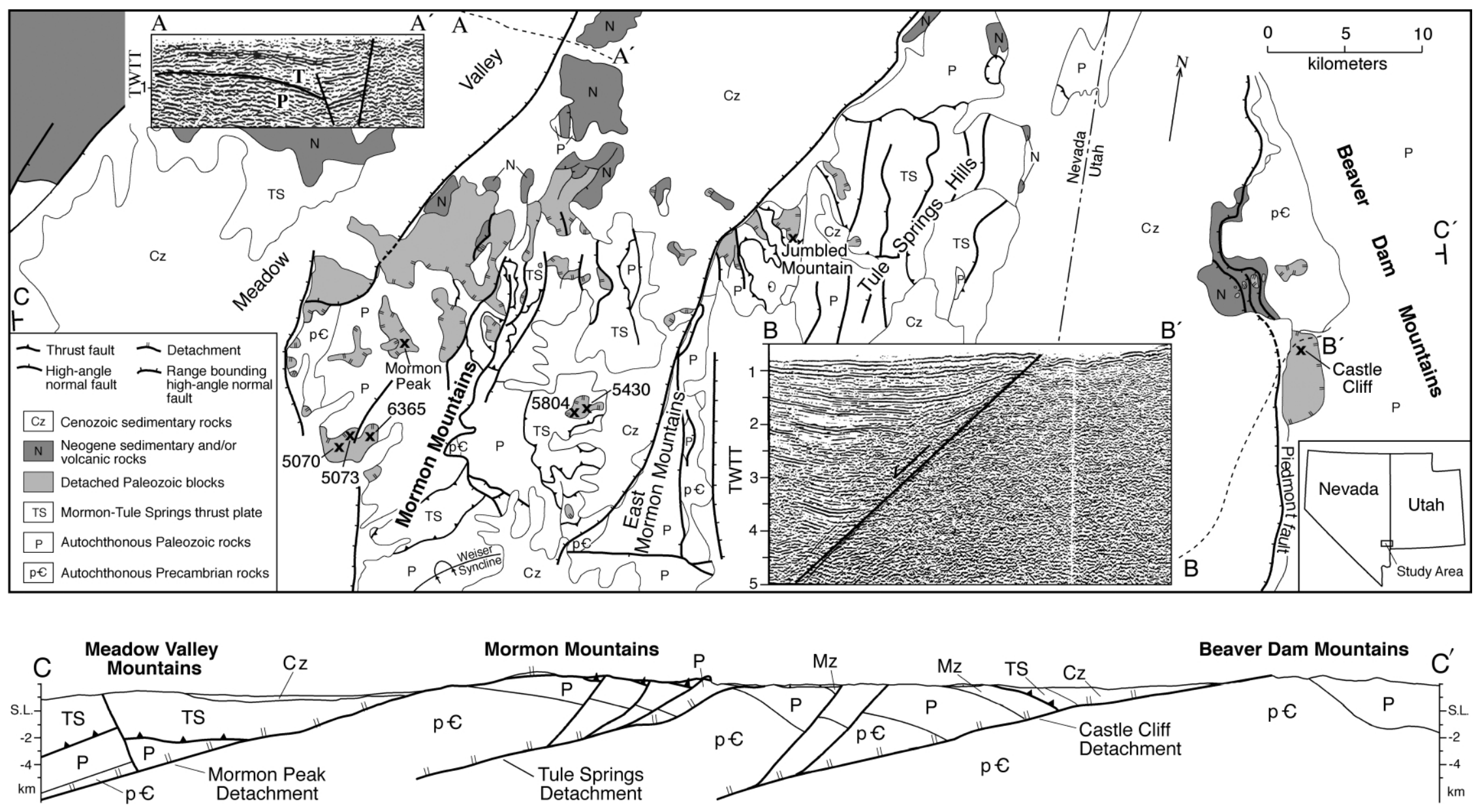

Figure 1. Generalized geologic map of the Mormon Mountains, Tule Springs Hills, and Beaver Dam Mountains. Modified from Tschanz and Pampeyan (1970), Wernicke et al. (1989), Anderson and Barnhard (1993), and Carpenter and Carpenter (1994). Inset seismic reflection profiles are from Carpenter and Carpenter (1994). More extensive seismic coverage is available from Carpenter and Carpenter (1994) along with details of acquisition parameters. Carpenter and Carpenter (1994) interpreted the true dip of the Beaver Dam normal fault interpreted in profile $\mathrm{BB}^{\prime}$ as $60^{\circ}$ west after correction for seismic velocity and obliquity of the section. Lower panel is a cross section modified from Wernicke et al. (1989), showing their interpretation of three major low-angle normal faults. Anderson and Barnhard (1993) and Carpenter and Carpenter (1994) both suggested, as do we, that the Beaver Dam and Mormon Mountains are bounded on their respective western margins by high-angle normal faults. 
slide block emplacement (Shaller 1991; Malone et al. 1999; Anders et al. 2000; Beutner and Gerbi 2005; Aharonov and Anders 2006). Comparable features, similarly attributed to fluidization, have been observed within rock avalanches, mud/debris flows, and laboratory experiments. These include concrete-like textures, normal and reverse internal grading (e.g., Vallance and Scott 1997; Pouliquen and Vallance 1999), and flow banding (Anders et al. 2000; Beutner and Gerbi 2005). The absence of evidence for crosscutting relations between dikes in many slide blocks (e.g., Johnson 1978; Pierce 1979; Shaller 1991) or for more than one generation of conglomerate is consistent with an origin involving a single deformational event (Anders et al. 2000).

The source (or sources) of the granular material associated with slide blocks is uncertain and may vary from one example to another. Krieger (1977) and Morris and Hebertson (1996) regarded the basal conglomerate as gravel that was overridden by the slide block during catastrophic emplacement, a view that is consistent with reports of wood fragments in both the basal layer and associated clastic dikes (Pierce 1979; Anders et al. 2000). In other examples, however, much of the fragmental material may have been derived from cataclasized rock immediately above or below the detachment surface.

Armored grains, consisting of rounded particles surrounded by halos of finer-grained material, are widely present in the basal conglomerates of slide blocks ranging in scale from order $10 \mathrm{~km}^{2}$ to 100 $\mathrm{km}^{2}$ (Anders et al. 2000; Beutner and Gerbi 2005). The halos differ from reaction rims because their composition is indistinguishable from the associated matrix and because elongate or tabular grains within halos parallel the surfaces of the armored particles. Halos are found preferentially around the largest grains in any given population, and they are best developed in the presence of abundant matrix. Armored grains found beneath the Heart Mountain slide block were initially interpreted by Beutner and Craven (1996) as "armored lapilli" associated with volcanic injection into the basal layer. Anders et al. (2000) suggested that they resulted from grainsize segregation and rolling in a fluidized medium, consistent with the environment at the base of a rapidly emplaced slide block in nonvolcanic as well as volcanic settings. Beutner and Gerbi (2005) hypothesized that particle accretion might be promoted by frictionally generated high temperatures. In their model, calcium carbonate dissociates to yield lime $(\mathrm{CaO})$ and $\mathrm{CO}_{2}$. The lime reacts with water to produce portlandite $\left(\mathrm{Ca}(\mathrm{OH})_{2}\right)$, which in turn combines with $\mathrm{CO}_{2}$ to produce calcium car- bonate again. The hypothesized armoring mechanism is applicable in a wide range of settings involving fluidization, including our observations of material associated with bolide impacts and explosive volcanic eruptions. In the case of slide blocks, we infer that the coating develops preferentially in the final stage of movement when interactions between particles are least energetic. This may explain why armoring is found only on large grains and in the presence of fine-grained matrix and not in association with grading.

The rate of emplacement for many large slide blocks is controversial. Boyer and Hossack (1992), Hauge (1993), and Davis and Friedmann (2005) all have suggested that the large slide blocks they studied were emplaced incrementally over long though unspecified spans of time. Although doubtful of the evidence presented for such interpretations, we nonetheless searched carefully for such relatively diagnostic features as multiple generations of dilatant veins, cataclastic flow structures and clastic dikes at the basal contacts of the detached blocks, and particularly for crosscutting relationships, features that might be expected where emplacement was slow or episodic.

\section{Seismically Cycled Faults}

Drawing on an extensive literature concerned with deformation along upper crustal faults, we focus here on attributes pertinent to modes of movement. Normal faults that are rooted in the crust move incrementally either in earthquake rupture events or via aseismic creep (see Scholz 2002). Distinguishing in outcrop between these modes of deformation is difficult (Cowan 1999; Cowan et al. 2003). However, both involve a discernible history of repeated rock breakage (e.g., Brock and Engelder 1977; House and Gray 1982; Chester and Logan 1986; Chester et al. 1993; Streit 1998). Brittle fault ruptures are typically associated with fluids from which minerals can precipitate, filling any space created by fracturing (e.g., Sibson et al. 1988). Here we focus on deformation associated with carbonates and quartz-rich sandstones because these are the rock types primarily involved in faulting in the Mormon Mountains.

Apart from macroscale patterns of brecciation in carbonate rocks (e.g., Tarasewicz et al. 2005), significant microscale variations are observed as a function of distance to a fault contact (Newman and Mitra 1994). Microscopic examination of carbonates in contact with large-displacement faults, both normal and thrust, reveals distinctive patterns of deformation for a given depth, temperature, and 
displacement history. Carbonates in contact with thrust faults that moved at shallow crustal depths typically exhibit grain-size reductions as a function of proximity to the fault contact, tectonic stylolites, mineral lineations, crosscutting veins, dynamic recrystallization, increased twinning with proximity to the fault, as well as preferred orientation of calcite twins and intense cataclasis (e.g., House and Gray 1982; Woital and Mitra 1986; Newman and Mitra 1994). Carbonates associated with normal faults that were active at similar depth ranges exhibit comparable deformation features. These include an increase in the abundance of undulose extinction, calcite twinning, preferred twin orientations, dynamic recrystallization, growth of new minerals and development of crosscutting veins, and a decrease in grain size, all as a function of proximity to fault contacts (e.g., Anders et al. 2001).

In rock composed primarily of feldspar and quartz, healed microfractures have been shown to develop aureoles around fault contacts (Engelder 1974; Anders and Wiltschko 1994; Vermilye and Scholz 1998). These are the result of mode 1 fractures formed during stress loading, and they are easily recognized on the basis of fluids and precipitates trapped along fracture surfaces (Tuttle 1949). Aureoles of healed microfractures represent a damage or process zone surrounding faults within the brittle field (Scholz et al. 1993), and they reflect prolonged and repeated stress accumulation along deeply buried parts of seismically cycled faults (see Anders and Wiltschko 1994; Anders et al. 2001). Our examination of quartz grains sampled beneath slide blocks, including very large examples such as the Heart Mountain detachment, indicates that healed microfractures do not develop in such settings. When microfractures are present at the base of large slides, they are typically wider than healed microfractures, and they show no evidence of the trapped fluid inclusions or the mineral precipitates distinctive of healed microfractures.

Cataclastic flow is commonly associated with seismically cycled fault zones, and it results in features reminiscent of fluidization. However, in contrast to our observations at slide blocks, cataclastic flow tends to parallel fault surfaces, with abundant evidence for crosscutting relationships (for numerous examples, see Snoke et al. 1998). Cataclastic dikes have been reported from thrust faults (e.g., Engelder 1974; Brock and Engelder 1977; Axen 1984), but they are extremely rare, filled by finegrained gouge, shale, and unconsolidated sandstone rather than conglomerate (e.g., $<25 \mu \mathrm{m}$ in diameter; Engelder 1974; also see Cowan et al. 2003), re- stricted to within a few meters of the fault zone, and found both below and above faults. Pseudotachylyte dikes are well known in seismically cycled faults (e.g., Magloughlin 1992; Magloughlin and Spray 1992) and at large slide blocks (e.g., Masch et al. 1985; Day et al. 1997), but they are not present in carbonate rocks.

\section{Geological Setting of the Mormon Peak Detachment}

The Mormon Peak detachment is one of three generally west-dipping detachment faults in the Mormon Mountains and Tule Spring Hills of southeastern Nevada and the Beaver Dam Mountains of southwestern Utah that are inferred on the basis of outcrop mapping to be both rooted and of regional extent (e.g., Wernicke 1982; Wernicke et al. 1985, 1989; Wernicke and Axen 1988; Axen and Wernicke 1989; Axen et al. 1990; Axen 1993, 2004). In combination with the Tule Springs and Castle Cliff detachments, this structure is thought to have accommodated more than $50 \mathrm{~km}$ of Basin and Range extension (Wernicke et al. 1988). Indeed, the Mormon Mountains-Beaver Dam Mountains transect has come to be regarded as a type example for lowangle normal faulting in the upper crust in an area in which no metamorphic core complex is exposed (see Wernicke 1995).

The Mormon Mountains constitute a topographic dome rising roughly $1 \mathrm{~km}$ above surrounding Cenozoic basin fill. Located within the Sevier (Cretaceous to early Cenozoic) fold and thrust belt, these mountains are composed of Precambrian crystalline rocks and Paleozoic through Mesozoic carbonate and clastic sedimentary rocks, as well as limited exposures of Cenozoic sedimentary and volcanic rocks (Tschanz and Pampeyan 1970; Olmore 1971; Wernicke 1982; Taylor 1984; Ellis 1985; Wernicke et al. 1985; Axen et al. 1990). The most significant thrust fault in the Mormon Mountains, the Mormon thrust, places Cambrian Bonanza King Formation on Lower Paleozoic to Permian rocks and, assuming that the fault is equivalent to the Tule Springs thrust in the adjacent Tule Springs Hills to the east, on rocks as young as Jurassic (Wernicke et al. 1985; Axen et al. 1990; Axen 2004). In the southern Mormon Mountains, the lower plate of the thrust forms a prominent northeast-trending, southeast-verging, overturned syncline-the Weiser syncline. Linkage of the thrusts in the Mormon Mountains to the Glendale/Muddy Mountain thrust system to the south has been inferred on the basis of a comparable fold (Olmore 1971; Skelly 1987; Axen et al. 1990). Although the Mormon Mountains 
are topographically domical, the distribution of stratal dip is significantly more complex in detail and, unlike metamorphic core complexes, which are domical features of similar dimensions, there is no evidence of mylonitization within the carbonate rocks. All deformation in the Mormon Mountains appears to be either brittle or related to pressure solution (see Anderson and Barnhard 1993; Diehl 2000).

The Mormon Mountains feature mapped as the Mormon Peak detachment is actually a series of isolated blocks (fig. 1) that are inferred to have been originally contiguous and associated with $\sim 25 \mathrm{~km}$ of west-southwest-directed normal slip (Wernicke 1982, 1995; Wernicke et al. 1985, 1988; Axen et al. 1990). A more or less conformable stratigraphic section from the upper Cambrian to the Pennsylvanian characterizes these blocks, with numerous highangle normal faults soling or terminating downward against the detachment surface on which displacement occurred.

Tschanz and Pampeyan (1970, p. 105) first suggested that younger Mississippian and Pennsylvanian rocks found in younger-over-older fault contact within the Mormon Mountains could have "slid by gravity down the flanks of the uplift." Although their mapping is not sufficiently detailed to provide a direct correlation, we assume that the features to which they referred are what Wernicke et al. (1985) later mapped as the Mormon Peak detachment and that Carpenter and Carpenter (1994) interpreted as a series of gravity-driven slide blocks. The Castle Cliff detachment (fig. 1) has likewise been inferred to represent a rootless slide block (Cook 1960; Jones 1963; Hintze 1986; Carpenter et al. 1989; Carpenter and Carpenter 1994). While the hypothesis of rootless deformation along these faults has remained very much the minority view in the structural geological community, it raises the general issue of how rooted and rootless deformation might be objectively distinguished.

\section{Mormon Peak Detachment at Block 6365}

One of the more spectacular exposures of the Mormon Peak detachment is a roughly $6-\mathrm{km}$-square block with an elevation of 6365 feet (Wernicke 1982; Wernicke et al. 1985, 1989). Block 6365 (fig. $1)$ is composed of a 300-400-m-thick section representing portions of the interval between the Cambrian Bonanza King Formation and the Pennsylvanian/Permian Bird Spring Formation. Sedimentary units within this block dip between $\sim 15^{\circ}$ and $\sim 60^{\circ}$ to the northeast, and they are structurally truncated at their base by a sharp, approximately planar surface that dips $15^{\circ}$ to the south-southwest and is easily recognized from a distance as a light tan band. A photograph of block 6365, along with nearby blocks 5070 and 5073, is described by Wernicke (1992, p. 558; his fig. 3) as "examples of detachment systems." Photographs of block 6365 are also exhibited by Wernicke et al. (1989; their fig. 3-3) and by Wernicke (1995; his fig. 2b). Within block 6365, several small-displacement, high-angle normal faults terminate downward against the detachment surface, geometry that is analogous to structural relationships interpreted from seismic images from the Sevier Desert of north-central Utah (Allmendinger et al. 1983) and seen in outcrop in metamorphic core complexes such as the Whipple Mountains of southeastern California (Lister and Davis 1989).

Immediately above the detachment surface at block 6365, Wernicke (1982) described a thin layer of conglomerate that he interpreted to have resulted from Sevier-aged overthrusting, followed by late Cenozoic "subterranean" fault zone capture. Carpenter and Carpenter (1994) suggested, on the basis of lithologic details, that the conglomerate is not of Cretaceous age but instead represents surficial deposits of Cenozoic age overridden by a gravity slide.

We excavated the contact on the eastern side of block 6365 (fig. 2). There, the detachment surface is striated and overlain by a $2-5-\mathrm{cm}$-thick zone of carbonate gouge. Directly above the gouge and of similar composition are the following rock types (shown in order in right-side inset of fig. 2): $\sim 0.5$ $\mathrm{m}$ of polymictic conglomerate graded in places and elsewhere unsorted, with a texture resembling concrete; $\sim 0.25 \mathrm{~m}$ of polymictic conglomerate mixed with rounded clasts derived from the overlying breccia $(\sim 30 \%) ; \sim 0.5 \mathrm{~m}$ of matrix-supported autobreccia overlain by several meters of jigsaw and crackle breccia (for breccia definitions, see legend of fig. 2; also Yarnold and Lombard 1989; Morris and Hebertson 1996). Although these unit contacts are shown as lines in figure 2, most are gradational, especially contacts between the matrix-supported autobreccia and jigsaw/crackle breccias. The jigsaw and crackle breccias are much more extensive than shown in figure 2 but with the level of brecciation generally decreasing away from the detachment. Although the detachment is poorly exposed beneath blocks 6365, 5070, and 5073 (fig. 1), it can be easily traced using conglomerate float.

The conglomerate layer consists predominantly of carbonate clasts with minor quartz grains $(<0.1 \%)$ and very rare grains of quartzite and chert. The conglomerate is texturally similar to concrete 
(top, fig. 3a-3c; middle top and bottom, fig. $3 d$ ), but in places it exhibits layering with both normal and inverse grading with respect to the orientation of the detachment surface (e.g., fig. 3e). At rare locations, the layering is truncated by internal channeling features that are reminiscent of streamdeposited sediments (fig. $3 \mathrm{f}$ ) and similar to features found in the basal conglomerate layers of landslides (for photograph, see Anders et al. 2000). Microscopic examination reveals that the larger grains tend to be rounded, while the fine- to very finegrained material is angular and interlocking. A similar texture has been observed in the basal sedimentary layer of the Heart Mountain slide block (Beutner and Gerbi 2005). The conglomerate at the base of block 6365 is composed mostly of dolomite grains. Less abundant limestone in the conglomerate corresponds to overlying Devonian rocks. Within the diverse clast population, occasional fragments $(<1 \%)$ consist of rounded, previously brecciated monolithologic carbonate. Although rare, some of the autobrecciated particles appear to be surrounded by colored smudges (fig. 3a, bottom). Microscopic examination of these smudges indicates that they are similar in composition to overlying matrix-supported carbonate breccia. However, the boundary between the smudge and the surrounding matrix material is irregular, with small lobes protruding outward from the main mass. We found similar smudgelike features in the basal conglomerate layer of slide blocks in the Canyon Range, Utah (Wills and Anders 1999). The origin of these unusual features is not well understood, but it may relate to grain disintegration within a flowing matrix.

Clastic Dikes. Above the detachment is a complex network of clastic dikes. The dike fill is identical in composition to the basal conglomerate. The abundance and width of dikes both decrease upward, as does the degree of brecciation surrounding the dikes, but both dikes and brecciation are more pervasive than illustrated in figure 2. Although a direct connection between the basal conglomerate and the dikes could not be established, owing to colluvial cover, their striking lithologic similarity suggests that they are genetically related. Where dikes are wide $(>0.5 \mathrm{~m})$, their fills are unsorted, but where they are narrow, they exhibit grading transverse to walls and channel structures typical of clastic dikes (e.g., Peterson 1968; Schmitt 1991). In some cases, breccia is invaded by small fingers of the conglomerate. Figure $3 g$ shows fossiliferous limestone laced with fine dikelets of light-brown carbonate. If the dikelets were removed, fractures and fossils on opposite sides of the dikelets would fit together again. This kind of fault zone breccia is similar to the fault zone dilation breccias described by Tarasewicz et al. (2005). At some locations, dikes abut a shear surface. However, there is no evidence that the conglomerate is either sheared or offset. Nowhere in the outcrop did we find any example of a conglomerate clast, that is, no evidence that clasts of an earlier conglomerate were incorporated into a second generation of conglomerate, as is demonstrably the case in the basal chlorite breccia in the Whipple Mountains.

Armored Grains. Armored grains were found in the basal conglomerate beneath block 6365 and in the associated clastic dikes (fig. 1; fig. $3 \mathrm{~h}$ for a photomicrograph from the Jumbled Mountain locality), although not at locations where grading is present. As observed in thin section, armoring is typically restricted to large grains isolated within a finergrained interlocking dolomite matrix. These details are similar to those recognized elsewhere by Anders et al. (2000) and by Beutner and Gerbi (2005). All of the armored grains at block 6365 are composed of carbonate. At other slide locations discussed by Anders et al. (2000), armoring is present in a wide range of lithologies but, in every case, in association with a carbonate matrix.

Microfracturing in the Conglomerate. Healed microfractures and minerals exhibiting undulose extinction are rare in the majority of quartz grains in the basal conglomerate layer. Microfracture density in isolated quartz grains and in carbonate-cemented sandstones within the conglomerate is also lower than observed in studies of fault zones of significantly smaller displacement by Anders and Wiltschko (1994) and Vermilye and Scholz (1998).

Damage Zone below the Detachment. Deformation of the Bonanza King Formation was studied at various intervals beneath block 6365, starting directly below the basal gouge layer and extending $100 \mathrm{~m}$ below the contact. The Bonanza King Formation is intensely brecciated at its upper contact. Within about $1 \mathrm{~m}$, the brecciation becomes significantly less intense. By $10 \mathrm{~m}$ below the detachment, the level of brecciation is distinguished with difficulty from Bonanza King Formation background deformation. In some of the most intensely brecciated samples, cataclastic flow features were observed in thin section but with no clear examples of crosscutting relations. Highly brecciated samples from within a few centimeters of the detachment contain interstitial fine-grained carbonate. White sparry calcite is present as fracture fill in some hand specimens (e.g., fig. $3 g$ ) both above and below the detachment and throughout the Mormon Mountains and is generally $\ll 1 \%$ by volume. On 


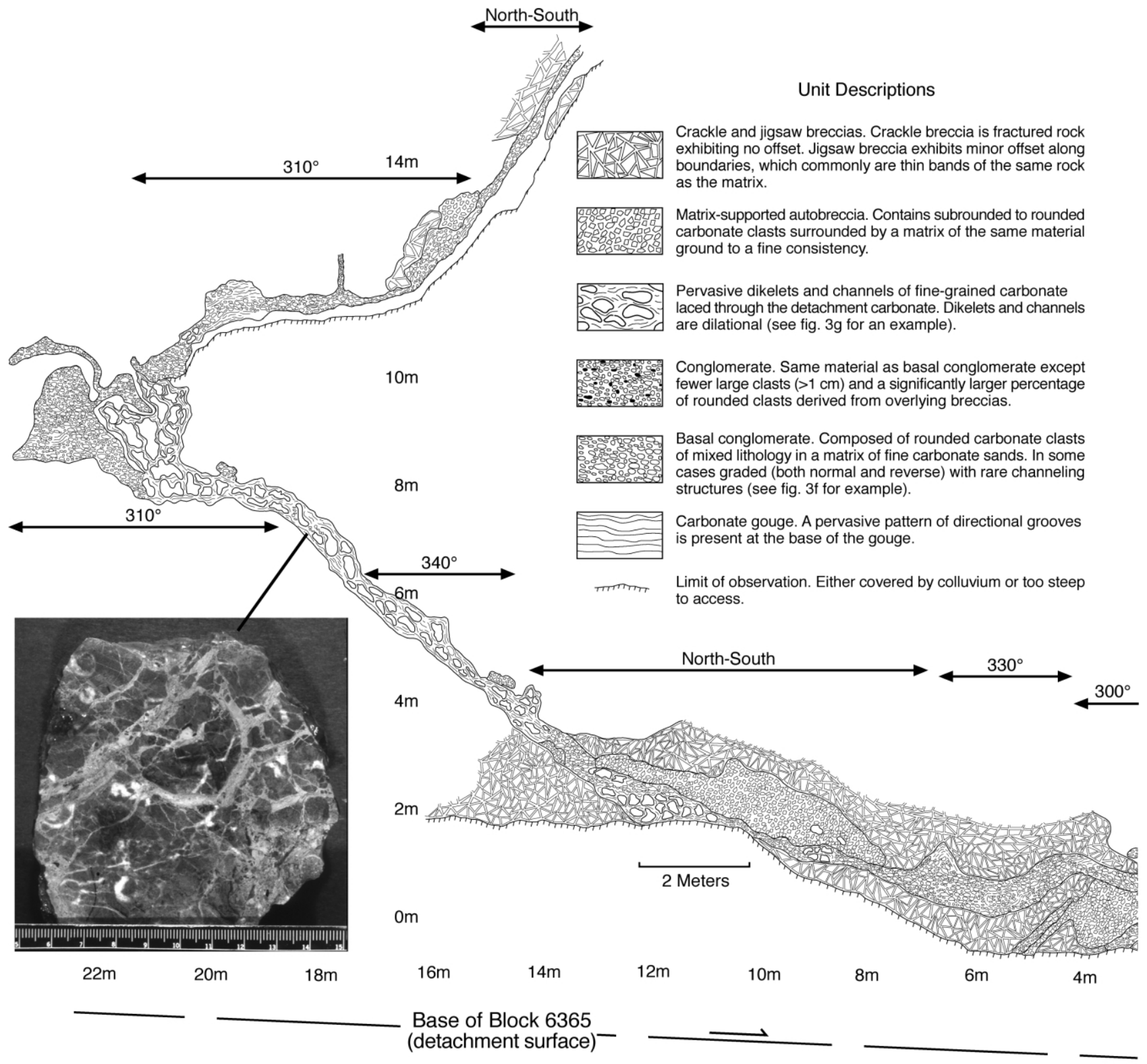

Figure 2. Oblique cross section of clastic dike network exposed at base of block 6365. View is generally toward the south to southwest. Double-headed arrows indicate orientation of face. Right inset is a detail of the basal contact exposed in a trench, with images of representative hand samples from the trench exposure. Image in the left inset shows a hand specimen laced by dikelets of fine-grained carbonate, symbolized by wavy lines in the cross section. The same specimen is shown in color in figure 3g. Deformation and diking are more extensive than shown.

the basis of palinspastic reconstruction assuming a rooted fault, Axen et al. (1990) inferred that rocks below the detachment were buried at $\sim 5-7 \mathrm{~km}$ /depending on the presumed thickness of prefaulting Pennsylvanian and younger rocks). Many deformation features expected of carbonates in fault zones active at these depth ranges are absent. These include grain size reduction, dynamic recrystallization, twinning, undulose extinctions, and crosscutting veins (discussed above).

Kinematic Indicators. Three kinds of kinematic indicators provide useful information about the movement direction of block 6365. As noted by Wernicke et al. (1985), prominent faults within 

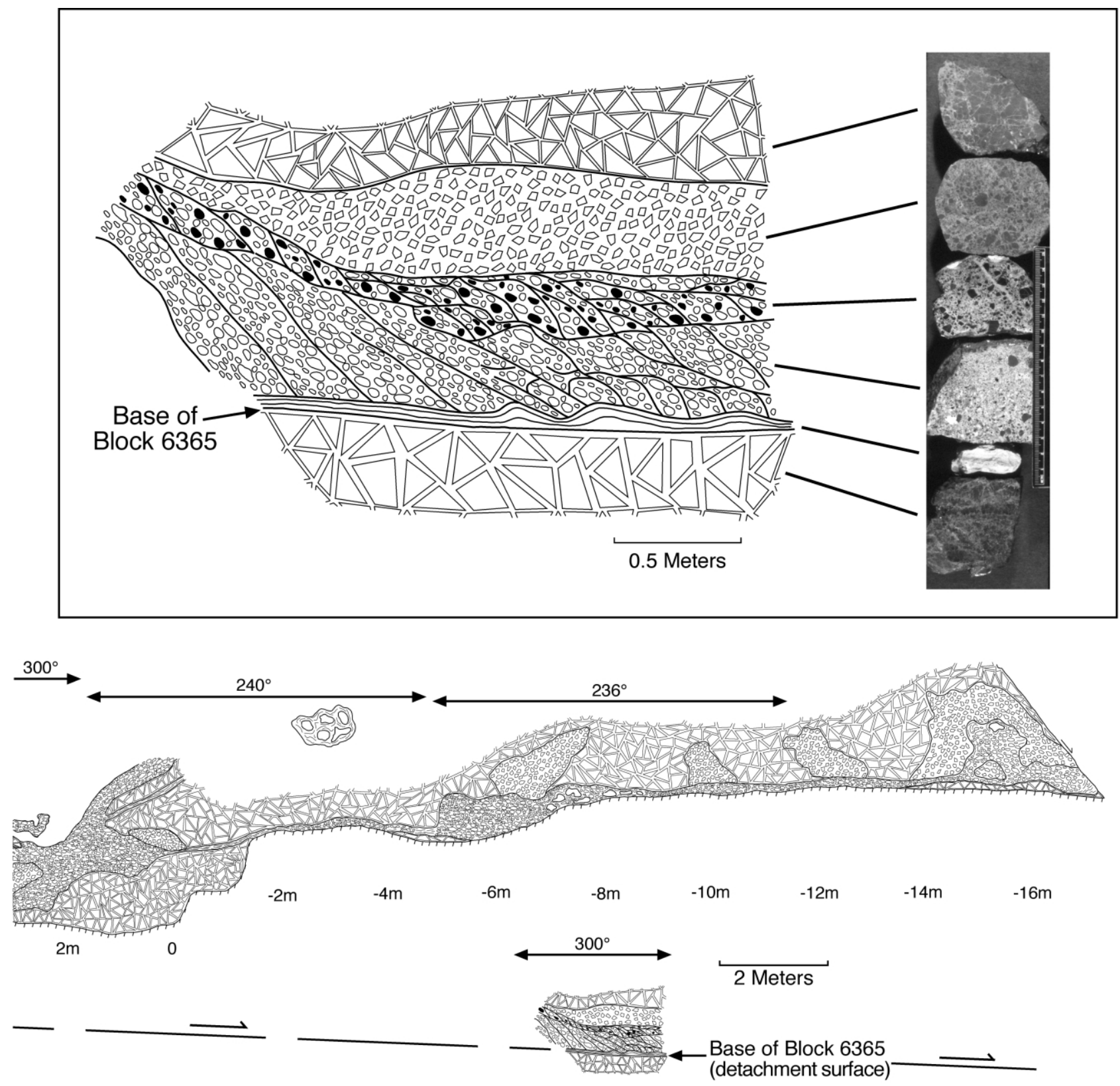

Figure 2 (Continued)

block 6365 dip to the southwest. At a smaller scale, we measured slickenline grooves along the detachment surface and minor faults and fractures in the basal conglomerate layer. The detachment itself is examined with difficulty owing to colluvial cover at most locations. In our trench at block 6365, a meter-square exposure of the base of the gouge layer reveals abundant slickenlines with a uniform trend of $195^{\circ}$ and plunge of $5^{\circ}$. Small-offset faults and fractures in the basal conglomerate strike $95^{\circ}$ and dip $12^{\circ} \mathrm{S}$ (fig. 2, right inset). In each case, the direction corresponds approximately to the modern direction of inclination of the detachment (southsouthwest) and is markedly different from the published regional extension direction $\left(\sim 255^{\circ}\right.$, on the basis of our interpretation of fig. 17 of Wernicke et al. [1985] and $255^{\circ} \pm 10^{\circ}$ from table 1, p. 1749 , of Wernicke et al. [1988]). Some of the faults within the basal conglomerate clearly deform the gouge layer, creating small folds (fig. 2, right inset). The 

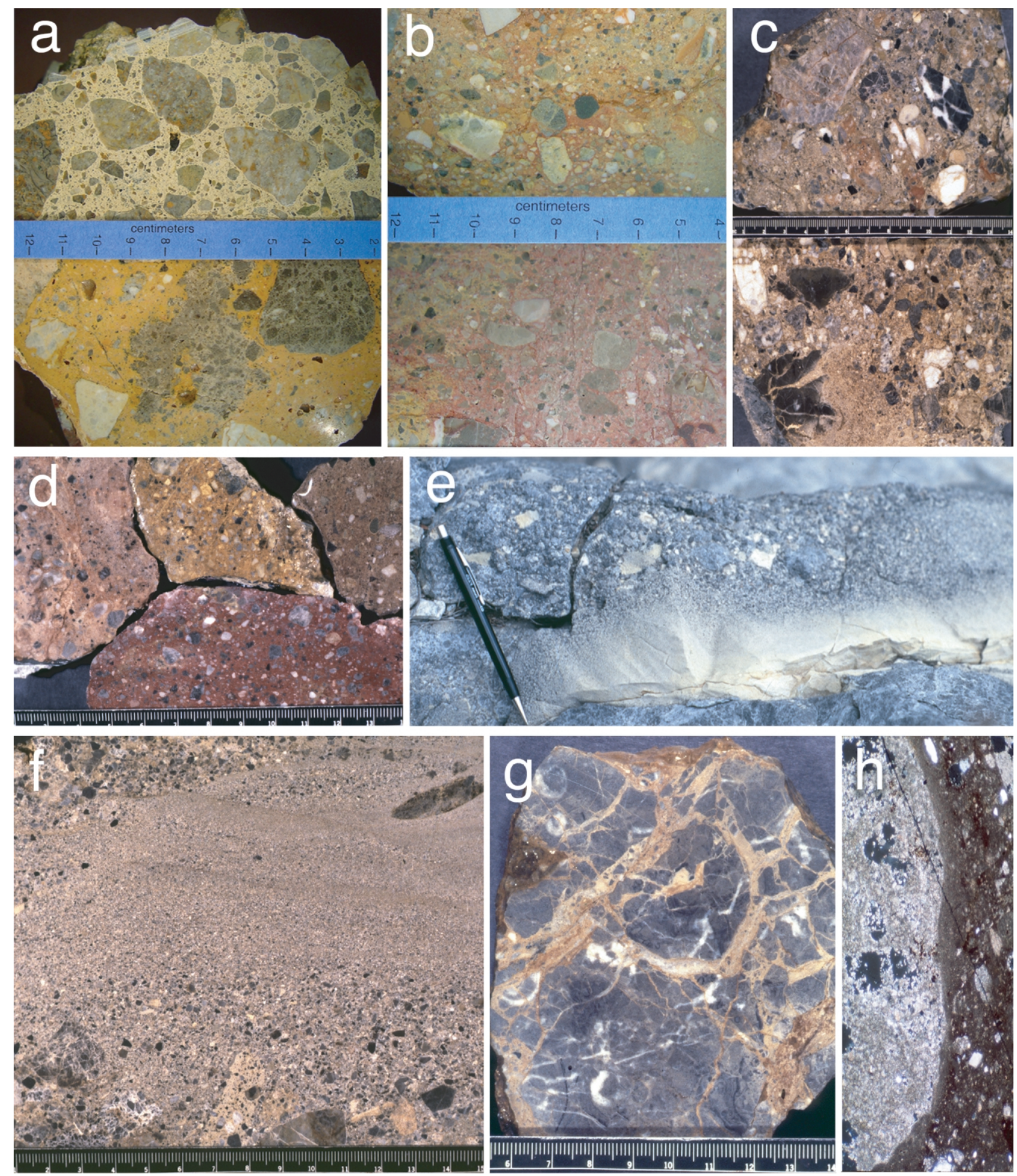

Figure 3. Samples from the basal layer of known slide blocks and from the bases of blocks in the Mormon Mountains and Tule Springs Hills mapped as the Mormon Peak detachment by Wernicke et al. (1985) and Axen (1993). $a-c$, Top, hand samples from the basal layer of detached blocks from the northwest, southwest, and eastern Mormon Mountains. Bottom, samples from the basal layer of known slide blocks in Idaho and Utah. $d$, Comparison of hand samples from the basal layer of detached blocks in the Mormon Mountains (middle top and bottom) with samples from the basal 
faults and fractures within the trench exposure appear to merge into the roughly subhorizontal contact between the basal conglomerate and overlying matrix-supported autobreccia, perhaps as a result of more distributed deformation at that level.

\section{Mormon Peak Detachment at Other Locations}

We have focused here on block 6365 because it is the first location at which a distinctive conglomerate was recognized at what is mapped as the Mormon Peak detachment. However, in tracing mapped contacts throughout the Mormon Mountains and the Tule Springs Hills, we have discovered other locations with considerably more extensive exposures of the basal conglomerate.

In the northwest Mormon Mountains, for example, there are numerous locations mapped by Taylor (1984) and Ellis (1985) as the Mormon Peak detachment, where the basal conglomerate can be walked out over distances of several kilometers. At one location, the layer can be followed continuously for about $10 \mathrm{~km}$. In each case, the conglomerate is texturally indistinguishable in hand specimen from that found at the base of block 6365 . Only the color is different (tan at block 6365 and gray or occasionally red in the northwest Mormon Mountains, as a result of later iron oxide precipitation). The thickness of the conglomerate varies from a few centimeters to about $1 \mathrm{~m}$, with clasts up to fist sized compared with a maximum clast size of no more than a few centimeters at block 6365.

In the Tule Springs Hills, the basal conglomerate layer at mapped locations of the Mormon Peak detachment (Axen 1993) is typically $<10 \mathrm{~cm}$ thick and generally reddish to tan in color. Both the basal layer and clastic dikes contain particles that are more angular and autobrecciated than is the case in the Mormon Mountains. The higher proportion of autobrecciated particles corresponds to a location at which the Mormon Peak detachment cuts to within a few meters of the Sevier-aged Tule Springs thrust (Axen 1993). Also, the basal layer in the Tule Springs Hills area commonly exhibits dis- solution features, as do overlying and underlying carbonate rocks. Although less well developed than at block 6365, clastic dikes in both the northwest Mormon Mountains and in the Tule Springs Hills can be traced directly to the basal conglomerate at several locations, consistent with our interpretation at block 6365.

Armored Grains. Although armored grains have been found in the basal conglomerate layer beneath every major block examined, some of the best examples come from the Mormon Peak detachment at Jumbled Mountain in the Tule Springs Hills (fig. $3 h$ ) and from the northwest Mormon Mountains. At several locations near Jumbled Mountain, a cleavage in fine-grained carbonate of the basal conglomerate wraps around larger undeformed carbonate clasts, yielding an appearance similar to armored grains, as described by Beutner and Gerbi (2005).

Kinematic Indicators. As is the case at block 6365 , kinematic indicators that we measured on what has been mapped as the Mormon Peak detachment by Taylor (1984), Ellis (1985), Wernicke et al. (1985), and Walker et al. (2004) are directed predominantly downdip and, in many cases, markedly oblique to the published orientation of regional extension. The divergence between movement indicators and the inferred extension direction is clearly seen in figure $4 a$, equaling or exceeding $45^{\circ}$ at nine locations (the "parallel" direction is $255^{\circ}$, as determined by Wernicke et al. [1988]). In contrast, the difference between the orientation of motion indicators and the present downdip direction for the detachment surfaces ("parallel" in fig. $4 b$ ) exceeds $45^{\circ}$ at only two locations. Figure $4 c$ shows figure $4 a$ data corrected for presumed doming in the extensional allochthon model, with no improvement in fit seen. Most significant in these data are values that exceed $45^{\circ}$ because most of the measurements are from locations at which the assumed extension direction is also the present dip direction.

Damage Zone below the Detachment. The degree of deformation associated with the detachment varies throughout the Mormon Mountains. However,

layer of known Pliocene slide blocks from the Basin and Range (right and left). e, Basal conglomerate with inverse grading from beneath a detached block in the northwestern Mormon Mountains. Pencil tip is on the basal detachment surface. $f$, Sample from basal layer of block 6365 exhibiting channeling features. $g$, Clastic dikelets recovered from Devonian limestone above the detachment at block 6365 (see fig. 2, left insert). Dikelets are composed of fine-grained particles of carbonate, which at high magnification appear interlocked. $h$, Thin-section micrograph of 1 -cm limestone clast from Jumbled Mountain showing armoring features discussed in text. All scales in centimeters. 


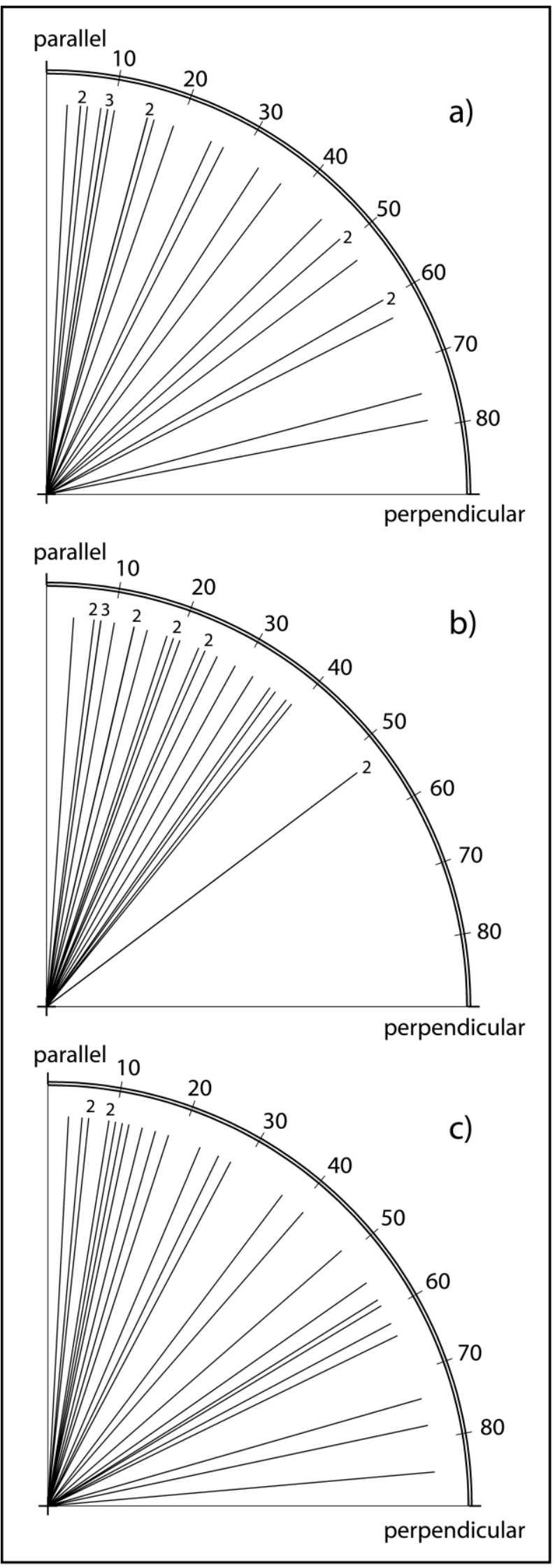

deformation above the detachment is nearly everywhere more intense than below the detachment. As is the case at block 6365, deformation is present in carbonate rocks up to several tens of meters above the detachment. Brecciation below the detachment typically decreases to background levels within a couple of meters and, in some places, as little as a few centimeters. Again, we found no evidence for grain-size reduction, dynamic recrystallization, preferred orientation of calcite twinning, or undulose extinction in any relationship to distance from the detachment. An examination of calcite veins above and below the detachment found no examples of crosscutting veining. The absence of crosscut veins was also observed in an extensive study of the base of the detachment by Diehl (2000).

At some locations, the detachment cuts to the level of the Tapeats Sandstone. Quartzite in this unit is intensely microfractured but without the exponential decrease in microfracture density as a function of distance from the Mormon Peak detachment that would be expected if the microfractures were related to the development of a process zone. Moreover, many quartz overgrowths found within $1 \mathrm{~cm}$ of the detachment have lower $\mathrm{mi}$ crofracture density than that observed for faults with orders-of-magnitude less displacement than that suggested for the Mormon Peak detachment (see Anders and Wiltschko 1994; Vermilye and Scholz 1998; Anders et al. 2001). Since the Tapeats Sandstone was fully lithified well before the Miocene, the observed pattern of microfracturing in the vicinity of the Mormon Peak detachment is not consistent with that observed at crustal faults elsewhere.

Fault Zone Geochemistry. Two studies of oxygen isotopes surrounding the detachment in the Mormon Mountains unfortunately provide little definitive information about whether the detachments

Figure 4. Orientation of kinematic indicators for the Mormon Peak detachment compared with $(a)$ the inferred $255^{\circ}$ extension direction of Wernicke et al. (1988) and $(b)$ the downdip direction for the detachment at each location. In each case, a deviation of $0^{\circ}$ means that kinematic indicators and reference orientations are parallel. $c$, Data shown in $a$ corrected under the assumption that the Mormon Mountains have been domed. The downdip direction is first rotated to horizontal about individual strike axes and then tilted around a $165^{\circ}$ axis to a $20^{\circ}$ southwest dip determined from Axen et al. (1990). Although this correction is a nonunique solution, we believe it is the most reasonable correction applicable. 
are rooted or not. Losh (1997) reported that oxygen isotopic data from close to the detachment yield a meteoric signature. He also presented calcite fluid inclusion data from along the base of several of the Mormon Mountains blocks from which he inferred homogenization temperatures between $70^{\circ}$ and $82^{\circ} \mathrm{C}$ (14 of 17 measurements), with three dolomite samples from beneath the detachment suggesting temperatures from $115^{\circ}$ to $130^{\circ} \mathrm{C}$. Diehl (2000) also reported oxygen isotope data from close to the Mormon Peak detachment. A negative $\delta^{18} \mathrm{O}$ shift of $\sim 10 \%-12 \%$ in the fault breccia is similar to that observed by Templeton et al. (1995) in brecciated rock at the base of the Heart Mountain slide block. Diehl (2000), like Losh (1997), interpreted the oxygen isotopic shift to indicate thermally elevated meteroic waters passing through brecciated rock at the base of the detached blocks, although it is not clear how she determined temperatures from the oxygen isotopic data. Depending on the assumed geothermal gradient, the data presented are consistent with several kilometers of overburden at the time of faulting, which can be interpreted as being consistent with either a landsliding model or the rooted detachment model.

\section{Reinterpretation of the Mormon Peak Detachment}

Taken together, our data cast doubt on the longaccepted interpretation of the Mormon Peak detachment as a regional-scale low-angle normal fault rooted in the midcrust (e.g., Wernicke et al. 1985; Axen 1993; Wernicke 1995). Instead, they support and amplify an interpretation first suggested by Tschanz and Pampeyan (1970) and Carpenter and Carpenter (1994) that rocks mapped as the detachment represent a series of discrete, substantially smaller, gravity-driven slide blocks catastrophically emplaced during the Miocene. The most important observations supporting a gravity-driven model are the presence at many localities of a distinctive basal conglomerate and associated clastic dikes, kinematic indicators that diverge markedly from the inferred regional extension direction, a thin carbonate gouge layer derived from the conglomerate, the lack of crosscutting veins, and the absence below the detachment of many of the deformation features expected of deeply rooted, seismically cycled detachments with the depth and displacement parameters suggested by Wernicke et al. (1985). Other individually less diagnostic features commonly associated with gravity-driven slide blocks include the presence of a razor-sharp contact, pervasive brecciation preferentially above the detachment, and a general increase in brecciation downdip at several localities.

The carbonate gouge beneath block 6365 is lithologically and texturally indistinguishable from a 2-4-cm-thick gouge found directly above the sharp contact at the base of a basal conglomerate layer of the Horse Creek slide block in the Lemhi Range, south-central Idaho (Beutner 1968; Anders et al. 2000). Both gouges are associated with abundant grooves of similar morphology, and they are similar in turn to grooves that we have examined in the basal "microbreccia" layer of the Heart Mountain slide block.

The development of extensive brecciation preferentially above the detachment is a characteristic of known slide blocks (e.g., Beutner 1968; Yarnold and Lombard 1989; Shaller 1991; Malone et al. 1999; Anders et al. 2000; Beutner and Gerbi 2005) and is widely observed in the Mormon Mountains, regardless of rock type. Although asymmetric deformation in similar rock types is observed at some seismically cycled faults, in many cases in the Mormon Mountains, rocks below the detachment are virtually undeformed even at the scale of a thin section.

The concrete-like texture of the conglomerate that directly overlies the gouge beneath block 6365 is commonly observed beneath gravity slide blocks (see Yarnold and Lombard 1989; Shaller 1991), as are armored grains, grading, and flow banding, which both Anders et al. (2000) and Beutner and Gerbi (2005) took to indicate fluidization during block emplacement. Matrix-supported autobreccia, which overlies the conglomerate layer in the Mormon Mountains, is widespread at every carbonate slide block we have examined as well as in numerous published examples (e.g., Yarnold and Lombard 1989; Shaller 1991; Morris and Hebertson 1996; Miller 1999|. Healed microfractures in quartz overgrowths are markedly less abundant than generally observed in fault zone studies (Anders and Wiltschko 1994; Vermilye and Scholz 1998). Clastic dikes of the type well developed above the Mormon Peak detachment are widely observed also in gravity slide blocks (Pierce 1979; Yarnold and Lombard 1989; Shaller 1991; Boyer and Hossack 1992; Malone et al. 1999; Wills and Anders 1999; Beutner and Gerbi 2005). In none of the known slide blocks that we have studied or in detachments of the Mormon Mountains (with one minor exception) is there evidence for more than one generation of dikes, either in the form of crosscutting relations or as conglomerate clasts in a dike. Clastic dikes in the Mormon Mountains also differ from those of seismically cycled faults in terms of aperture, total vol- 
ume, and persistence away from the detachment surface, as well as size distribution of infill material (see Engelder 1974; Sibson 1975; Johnson 1978; Yarnold and Lombard 1989; Shaller 1991). More specifically, the clastic dike network at block 6365 does not involve pseudotachylytes (not expected in carbonates), gouge, and/or significant cataclasis (very rare examples were found), as are observed in association with seismically cycled faults (e.g., Engelder 1974; Karson et al. 1998; Cowan et al. 2003). Thin-section analysis of thrust-related dikes described by Engelder (1974) and Axen (1984) shows that the materials involved are very different from those documented in this study. Grading and channel structures of the kind observed in clastic dikes of the Mormon Mountains are not known in thrustrelated dikes, but they are similar to features found in clastic dikes in sedimentary successions (Peterson 1968; Schmitt 1991).

Alternative Explanations for the Conglomerate. The explanation suggested by Wernicke (1982, p. 120) for the basal conglomerate is not plausible on the basis of the evidence presented here. Wernicke proposed that the conglomerate represents synorogenic sediment overridden in Cretaceous time by a Mesozoic thrust and somehow transferred to the Mormon Peak detachment during Miocene extension. However, the composition of the conglomerate differs from that of the syntectonic gravels of the region (see Carpenter and Carpenter 1994), and it is difficult to construct a scenario in which the gravels remained unlithified for more than 50 million years, before being transferred to the fault zone of a crosscutting normal fault.

We also exclude the possibility that the conglomerate represents karst infill (see Axen 2004). The textures and geometry of conglomerate layers are inconsistent with a karst interpretation (see James and Choquette 1988), and their composition in the basal layer of blocks such as block 6365 (dolomitic) is inconsistent with its superjacent source (predominantly limestone). Throughout the Mormon Mountains, the conglomerate was intimately involved in the emplacement of what we have interpreted to be slide blocks. Nowhere is conglomerate observed truncated beneath the detachment. This is not to say that karst infill and solution cavities are absent above and below the detachment. Clear examples have been recognized throughout the Mormon Mountains (e.g., Anderson and Barnhard 1993; Diehl 2000), and such features are particularly common in the eastern part of the range and adjacent Tule Springs Hills, with appreciable removal of allochthonous carbonate units (see Diehl 2000). However, karst is simply not the cor- rect interpretation for the basal conglomerate layer observed in the Mormon Mountains or for conglomerate layers observed at the base of known slide blocks found elsewhere in the world.

Block Emplacement. All of the available observations can be accommodated by a model in which blocks broke loose from the upper plate of the Mormon Peak thrust and moved rapidly downhill, radially away from the crest of the Mormon Mountains, as it was at the time. What triggered sliding is unknown. However, the presence of high-angle normal faults throughout the Mormon Mountains, some demonstrably older than the Mormon Peak detachment (Walker et al. 2004), leads plausibly to the suggestion that earthquake activity might have been a contributing factor, along with steep topographic gradients. As sliding began, the fluidization of broken rock, with or without a role for water, is thought to have led to particle-particle recoil, a reduction of friction at the detachment zone, and the development of elevated fluid pressure, consistent with the existence of clastic dikes (Campbell et al. 1995; Anders et al. 2000; Aharonov and Anders 2006). Loss of fluid pressure associated with the breakup of the detached block is inferred to have led to frictional heating and to sintering of calcium carbonate, creating lime and $\mathrm{CO}_{2}$ gas (Beutner and Gerbi 2005). Later reaction of lime with water and $\mathrm{CO}_{2}$ may account for the observed interlocking crystal structure of the matrix material and general concrete-like texture of the granular material. In the case of block 6365, we hypothesize that the gouge layer would have developed at that time, grinding and fracturing the newly strengthened conglomerate. Macroscopically ductile deformation of the gouge at the termini of the smalldisplacement faults and fractures, which steepen downward into the gouge, is consistent with the acquisition of strength in the basal layer. That the same faults and fractures become subhorizontal as they approach the contact with overlying matrixsupported autobreccia suggests that the slide block continued to have momentum. It is possible, however, that these minor offset fractures/faults developed as a result of a small amount of postsliding deformation.

All of the observed detachment contacts developed within lithified Paleozoic rock. We know of no place in available outcrop in the Mormon Mountains where slide blocks advanced over Cenozoic sediments. However, we cannot entirely exclude a contribution of surficial sediments to the fluidized materials, as argued by Carpenter and Carpenter (1994).

The timing of block emplacement is not well 


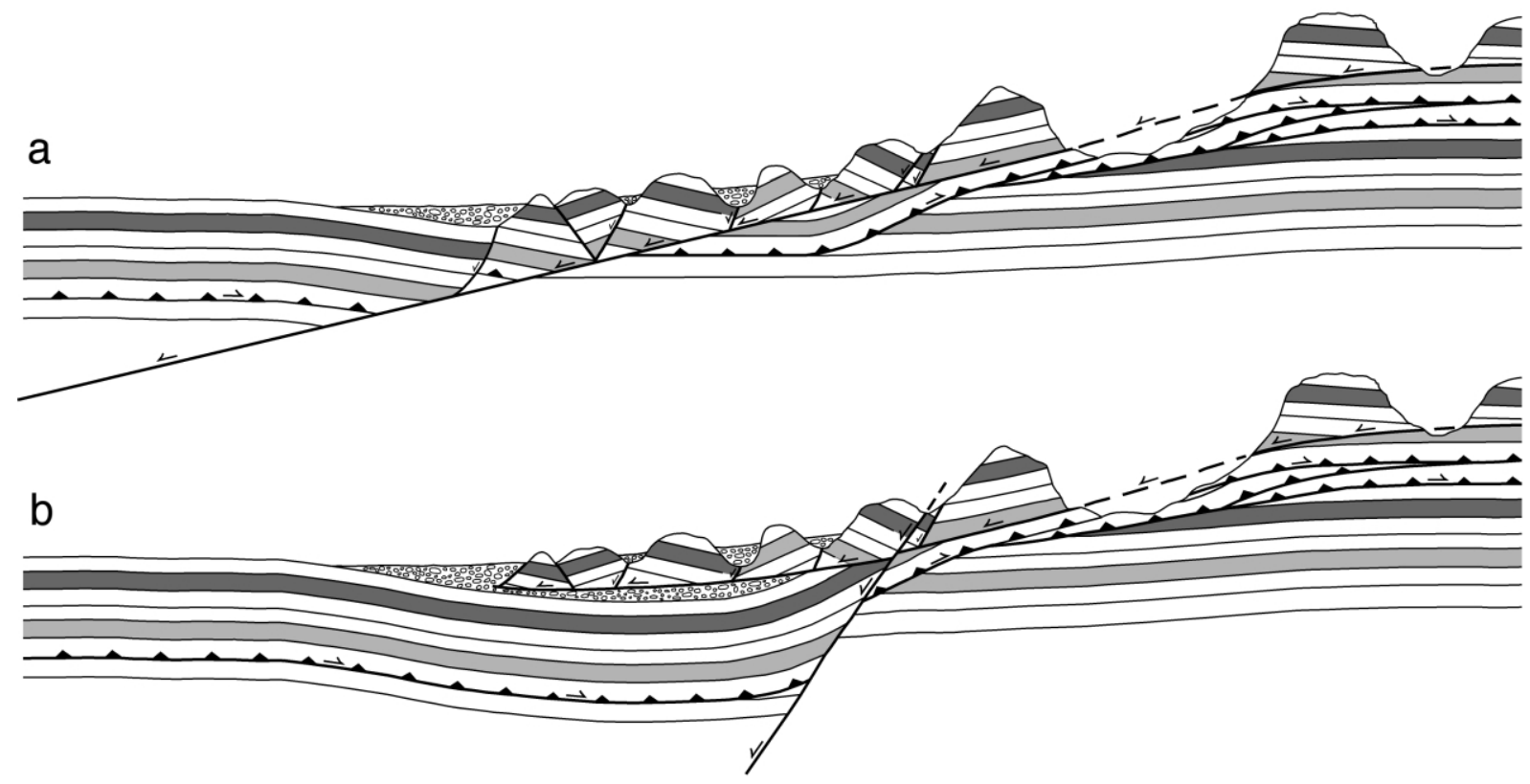

Figure 5. Two possible interpretations of hypothetical detached blocks, making use of the same surface geology. $a$, Low-angle normal fault rooted into the midcrust and accommodating appreciable extension. $b$, Rootless detachment flattening into surficial gravels and associated with no crustal extension. In each case, the blocks are partially buried by younger gravels downdip.

established. It appears to have taken place after 13.6 $\mathrm{Ma}$, on the basis of our determination of a $13.61 \pm 0.06-\mathrm{Ma}{ }^{40} \mathrm{Ar} /{ }^{39} \mathrm{Ar}$ age for a tectonically tilted andesite flow located within a chaotic assemblage of volcanic rocks on the northwestern flank of the Mormon Mountains. The time of emplacement of other slide blocks is for the most part unconstrained. A Miocene rather than significantly younger age for deformation is consistent with the superposition of the present erosional topography on the already deformed rocks.

Toes and Source Areas. Wernicke (1982, p. 124) argued against a "mega-landslide" origin for the Mormon Peak detachment because "toe" relationships "indicative of shortening in the ranges to the west" are not observed. We agree that a single mega-landslide is unreasonable. Our preferred interpretation is that smaller individual blocks moved downslope radially, not in a single direction and not necessarily at the same time.

The largest of these gravity slides is located in the northwest Mormon Mountains and moved in a northwesterly direction (fig. 1). This slide mass includes all of what was defined as the upper plate of the Mormon Peak detachment by Ellis (1985) and some of what was mapped by Taylor (1984) in the western part of the Mormon Mountains and by Wernicke et al. (1985) in the central part of the range. Within this large slide mass are smaller blocks that were emplaced after the larger mass (Walker et al. 2004). It is not clear whether these later slides broke off from within the larger slide mass or from higher elevations in the upper plate of the Mormon thrust, overriding blocks already emplaced at lower elevations. Mesozoic thrust stacking in the northwest Mormon Mountains placed Ordovician rocks on Mississippian rocks and thus created a higher source region for slides in that area relative to the lower elevation in the Meadow Valley Wash to the northwest. This elevation difference, which was subsequently increased by the development of a high-angle fault along the west flank of the range (fig. 1, inset $A A^{\prime}$ ) in a manner similar to that shown in figure $5 b$, would have permitted rocks of late Paleozoic age to slide down onto or next to rocks of equivalent age. Figure 5 shows how an exposed detachment projected into the subsurface, like the detachment exposed in the northwestern Mormon Mountains, might be misconstrued to be rooted when it is not. Therefore, Wernicke's (1982) conclusion that similar-aged rocks atop the Mormon Peak detachment in the northwest Mormon Mountains and in the Meadow Valley Wash (fig. 1) demand a continuous extensional allochthon is unfounded. Stratal orientation in blocks in the northwestern Mormon Mountains 
varies widely and is, in some cases, near vertical to overturned. This jumbled arrangement is comparable to that documented in slide blocks throughout the western United States (e.g., Secor 1963; Moores 1968; Moores et al. 1968; Beutner 1972; Pierce 1980; Moore et al. 1987; Boyer and Hossack 1992; Davis and Friedmann 2005), and it cannot be used to argue for any particular emplacement direction.

Most of the large slide blocks place the upper plate of the Mormon thrust against the lower plate. Their emplacement would have accelerated the exhumation of lower plate rocks in the central Mormon Mountains. The block that now includes Mormon Peak, the highest point in the range, is perhaps the most enigmatic. However, it is not uncommon for slide blocks more than a few million years old to lack obvious sources, owing to the subsequent modification of topography (e.g., Beutner 1968; Moores et al. 1968; Moore et al. 1987; Boyer and Hossack 1992; Wills and Anders 1999).

Several authors have suggested that what Wernicke and Axen (1988), Wernicke et al. (1989), and Axen et al. (1990) identified as the large-displacement Castle Cliff detachment on the west side of the Beaver Dam Mountains is actually one or more gravity-driven slide blocks (Reber 1952; Cook 1960; Jones 1963; Hintze 1986; Carpenter et al. 1989; Carpenter and Carpenter 1994; Anders et al. 1998). A published seismic reflection profile (Carpenter and Carpenter 1994) that obliquely intersects the transect in which the Castle Cliff detachment is drawn (Wernicke et al. 1989; Axen et al. 1990) shows no evidence for the detachment at depth (cf. inset $\mathrm{BB}^{\prime}$ and cross section $\mathrm{CC}^{\prime}$ in fig. 1). Evidence for upper crustal low-angle normal faults is also absent in seismic reflection data to the south of the Mormon Mountains and Tule Springs Hills (Bohannon et al. 1993). Instead, the Beaver Dam Mountains are seen to be bounded by a high-angle normal fault. In that case, the magnitude of regional extension from the Mormon Mountains to the Beaver Dam Mountains has likely been appreciably overestimated, with the
$25 \%-30 \%$ extension suggested by Anderson and Barnhard (1993) and the 18-24 km of extension estimated by Bohannon et al. (1993) being closer to the true value.

\section{Conclusions}

Examination of the Mormon Peak detachment in the Mormon Mountains, Nevada, reveals that it lacks many of the characteristics of seismically cycled faults and instead displays many of the features of rapidly emplaced gravity slide blocks. These include a distinctive basal conglomerate and associated clastic dikes, lack of expected deformation features beneath the detachment, and kinematic indicators that diverge from the inferred regional extension direction. The example is important because in the early 1980s it represented a point of departure in thinking about the possible role of low-angle normal faults in upper crustal extension and because it contributes to large estimates for crustal extension in the central Basin and Range Province. We suspect that similarly misinterpreted structures are embedded within the geologic literature and that they may be responsible for significant overestimation of crustal extension.

\section{A C K N O W L E D G M E T S}

We thank numerous individuals for help in the field and for insights about the geology, and especially those who participated in digging deep holes on hot days. These include E. Anderson, D. Rodgers, T. Nagel, S. Wills, J. Walsh, J. Carpenter, P. Almasi, M. Spiegelman, S. Losh, and J. Cooper. We also thank two anonymous reviewers for many helpful comments and Maureen Anders for help with graphics. This work was supported by National Science Foundation grant 99-02782. Also, acknowledgment is made to the Donors of the Petroleum Research Fund of the American Chemical Society for partial support of this research through grants 32914-AC2 and 39709-AC8.

\section{R E F E R E N C E S C I T E D}

Abers, G. A. 1991. Possible seismogenic shallow-dipping normal faults in the Woodlark-D'Entrecasteaux extensional province, Papua New Guinea. Geology 19: 1205-1208.

Abers, G. A.; Mutter, C. Z.; and Fang, J. 1997. Shallow dips on normal faults during rapid extension: earthquakes in the Woodlark-D'Entrecasteaux rift system, Papua New Guinea. J. Geophys. Res. 102:15,30115,317 .
Aharonov, E., and Anders, M. H. 2006. Hot water: a possible solution to the Heart Mountain detachment problem? Geology 34:165-168.

Allmendinger, R. W.; Sharp, J. W.; Von Tish, D.; Serpa, L.; Brown, L.; Kaufman, S.; Oliver, J.; and Smith, R. B. 1983. Cenozoic and Mesozoic structure of the eastern Basin and Range Province, Utah, from COCORP seismic-reflection data. Geology 11:532-536.

Anders, M. H. 1990. Late Cenozoic evolution of Grand 
and Swan Valleys, Idaho. In Roberts, S., ed. Geologic field tours of western Wyoming and parts of adjacent Idaho, Montana and Utah. Geol. Surv. Wyo. Public Inf. Circ. 29:14-25.

Anders, M. H.; Aharonov, E.; and Walsh, J. J. 2000. Stratification of granular media at the base of large slide blocks. Geology 28:971-974.

Anders, M. H.; Christie-Blick, N.; Wills, S.; and Krueger, S. W. 2001. Rock deformation studies in the Mineral Mountains and Sevier Desert of west-central Utah: implications for upper crustal low-angle normal faulting. Geol. Soc. Am. Bull. 113:895-907.

Anders, M. H.; Walsh, J. J.; and Christie-Blick, N. 1998. Fluidization events in detachment zones: evidence for catastrophic emplacement of large slide blocks. Geol. Soc. Am. Abstr. 30:3.

Anders, M. H., and Wiltschko, D. V. 1994. Microfracturing, paleostress and the growth of faults. J. Struct. Geol. 16:795-815.

Anderson, R. A. 1948. Reconnaissance survey of the geology and ore deposits of the south-western portion of the Lemhi Range, Idaho. Idaho Bur. Mines Geol. Pamph. 80, 18 p.

Anderson, R. E., and Barnhard, T. P. 1993. Heterogeneous Neogene strain and its bearing on horizontal extension and horizontal and vertical contraction at the margin of the extensional orogen, Mormon Mountains area, Nevada and Utah. U.S. Geol. Surv. Bull. 2011: 43.

Armstrong, R. L. 1972. Low-angle (denudation) faults, hinterland of the Sevier orogenic belt, eastern Nevada and western Utah. Geol. Soc. Am. Bull. 83:1729-1754.

Axen, G. J. 1984. Thrusts in the eastern Spring Mountains, Nevada: geometry and mechanical implications. Geol. Soc. Am. Bull. 95:1202-1207.

- 1993. Ramp-flat detachment faulting and lowangle normal reactivation of the Tule Springs thrust, southern Nevada. Geol. Soc. Am. Bull. 105:10761090.

- 1999. Low-angle normal fault earthquakes and triggering. Geophys. Res. Lett. 26:3693-3696.

- 2004. Mechanics of low-angle normal faults. In Karner, G. D.; Taylor, B.; Driscoll, N. W.; and Kohlstedt, D. L., eds. Rheology and deformation of the lithosphere at continental margins. New York, Columbia University Press, p. 46-91.

Axen, G. J., and Wernicke, B. P. 1989. Comment and reply on "On the role of isostasy in the evolution of normal fault systems." Geology 17:775-776.

Axen, G. J.; Wernicke, B. P.; Skelly, M. F.; and Taylor, W. J. 1990. Mesozoic and Cenozoic tectonics of the Sevier thrust belt in the Virgin River Valley area, southern Nevada. In Wernicke, B. P., ed. Basin and range extension tectonics near the latitude of Las Vegas, Nevada. Geol. Soc. Am. Mem. 176:123-153.

Beutner, E. C. 1968. Structure and tectonics of the southern Lemhi Range Idaho. PhD dissertation, Pennsylvannia State University, College Station.

1972. Reverse gravitative movement on earlier overthrusts, Lemhi Range, Idaho. Geol. Soc. Am. Bull. 83:839-846.

Beutner, E. C., and Craven, A. E. 1996. Volcanic fluidization and the Heart Mountain detachment, Wyoming. Geology 24:595-598.

Beutner, E. C., and Gerbi, G. P. 2005. Catastrophic emplacement of the Heart Mountain block slide, Wyoming and Montana, U.S.A. Geol. Soc. Am. Bull. 117: 724-735.

Bohannon, R. G.; Grow, J. A.; Miller, J. J.; and Blank, R. H., Jr. 1993. Seismic stratigraphy and tectonic development of Virgin River depression and associated basins, southeastern Nevada and northwestern Arizona. Geol. Soc. Am. Bull. 105:501-520.

Boyer, S. R., and Allison, M. L. 1987. Estimates of extension in the Basin and Range Province. Geol. Soc. Am. Abstr. Program 19:597.

Boyer, S. E., and Hossack, J. R. 1992. Structural features and emplacement of surficial gravity-slide sheets, northern Idaho-Wyoming thrust belt. In Link, P. K.; Kuntz, M. A.; and Platt, L. B., eds. Regional geology of eastern Idaho and western Wyoming. Geol. Soc. Am. Mem. 179:197-213.

Brock, W. G., and Engelder, T. 1977. Deformation associated with the movement of the Muddy Mountain overthrust in the Buffington window, southeastern Nevada. Geol. Soc. Am. Bull. 88:1667-1677.

Campbell, C. S.; Cleary, P. W.; and Hopkins, M. 1995. Large-scale landslide simulations: global deformation velocities and basal friction. J. Geophys. Res. 100: 8267-8283.

Carpenter, J. A., and Carpenter, D. G. 1994. Analysis of basin-range and fold-thrust structure, and reinterpretation of the Mormon Peak detachment and similar features as gravity slide systems; southern Nevada, southwestern Utah, and northwest Arizona. In Dobbs, S. W., and Taylor, W. J., eds. Structural and stratigraphic investigations and petroleum potential of $\mathrm{Ne}$ vada, with special emphasis south of the Railroad Valley producing trend. Nev. Pet. Soc. Conf. Vol. 2, p. $15-52$.

Carpenter, D. G.; Carpenter, J. A.; Bradley, M. D.; Franz, U. A.; and Reber, S. J. 1989. Comment and reply on "On the role of isostasy in the evolution of normal fault systems." Geology 17:774-775.

Chester, F. M.; Evans, J. P.; and Biegel, R. L. 1993. Internal structure and weakening mechanisms of the San Andreas fault. J. Geophys. Res. 98:771-786.

Chester, F. M., and Logan, J. M. 1986. Implications for mechanical properties of brittle faults from observations of the Punchbowl fault zone. Pure Appl. Geophys. 124:79-106.

Collettini, C., and Sibson, R. H. 2001. Normal faults, normal friction? Geology 29:927-930.

Cook, E. F. 1960. Breccia blocks (Mississippian) of the Welcome Spring area, southwest Utah. Geol. Soc. Am. Bull. 71:1709-1712.

Cowan, D. S. 1999. Do faults preserve a record of seismic slip? a field geologist's opinion. J. Struct. Geol. 21:9951001 . 
Cowan, D. S.; Cladouhos, T. T.; and Morgan, J. K. 2003. Structural geology and kinematic history of rocks formed along low-angle normal faults, Death Valley, California. Geol. Soc. Am. Bull. 115:1230-1248.

Davis, G. A., and Friedmann, S. J. 2005. Large-scale gravity sliding in the Miocene Shadow Valley supradetachment basin, eastern Mojave Desert, California. Earth-Sci. Rev. 73:149-176.

Day, S. J.; Carracedo, J. C.; and Guillou, H. 1997. Age and geometry of an aborted rift flank collapse: the San Andres fault system, El Hierro, Canary Islands. Geol. Mag. 134:523-537.

Diehl, S. F. 2000. Channeled fluid flow and massive dissolution along low-angle normal faults, eastern Basin and Range. PhD dissertation, Colorado School of Mines, Golden.

Ellis, B. J. 1985. Thin-skinned extension superposed on frontal Sevier thrust faults, Mormon Mountains, southern Nevada. MS thesis, Syracuse University, Syracuse, NY.

Engelder, T. 1974. Cataclasis and the generation of fault gouge. Geol. Soc. Am. Bull. 85:1515-1522.

Friedmann, S. J. 1997. Rock-avalanche elements of the Shadow Valley basin, eastern Mojave Desert, California: processes and problems. J. Sediment. Res. 67:792804.

Hauge, T. A., 1993. The Heart Mountain detachment, northwestern Wyoming: 100 years of controversy. In Snoke, A. W.; Steidtmann, J. R.; and Roberts, S. M., eds. Geology of Wyoming. Geol. Surv. Wyo. Mem. 5: 530-571.

Hintze, L. F. 1986. Stratigraphy and structure of the Beaver Dam Mountains, southwestern Utah. In Griffin, D. T., and Phillips, W. R., eds. Thrusting and extensional structures and mineralization in the Beaver Dam Mountains, southwestern Utah. Utah Geol. Assoc. Publ. 15:1-36.

House, W. M., and Gray, D. R. 1982. Cataclasites along the Saltville thrust, USA, and their implications for thrust-sheet emplacement. J. Struct. Geol. 4:257-269.

Jackson, J. A., and White, N. J. 1989. Normal faulting in the upper continental crust: observations from regions of active extension. J. Struct. Geol. 11:15-36.

Jackson, M. P. A.; Roberts, D. G.; and Snelson, S. 1995. Salt tectonics: a global perspective. Am. Assoc. Pet. Geol. Mem. 65, 454 p.

James, N. P., and Choquette, P. W., eds. 1988. Paleokarst. New York, Springer, 416 p.

Johnson, B. 1978. Blackhawk landslide, California, U.S.A. In Voight, B., ed. Rockslides and avalanches (vol. 1): natural phenomena. New York, Elsevier, Dev. Geotech. Eng. 14A:481-504.

Jones, R. W. 1963. Gravity structures in the Beaver Dam Mountains, southwest Utah. Intermount. Assoc. Pet. Geol. Guidebook 12:90-95.

Karson, J. A.; Brooks, C. K.; Storey, M.; and Pringle, M. S. 1998. Tertiary faulting and pseudotachylytes in the East Greenland volcanic rifted margin: seismogenic faulting during magmatic construction. Geology 26: 39-42.
Krieger, M. H. 1977. Large landslides, composed of megabreccia, interbedded in Miocene basin deposits, southeastern Arizona. U.S. Geol. Surv. Prof. Pap. 1008, 25 p.

Lister, G. S., and Davis, G. A. 1989. The origin of metamorphic core complexes and detachment faults formed during Tertiary continental extension in the northern Colorado River region, U.S.A. J. Struct. Geol. 11:65-94.

Losh, S. 1997. Stable isotope and modeling studies of fluid-rock interaction associated with the Snake Range and Mormon Peak detachment faults, Nevada. Geol. Soc. Am. Bull. 109:300-323.

Magloughlin, J. F. 1992. Microstructural and chemical changes associated with cataclasis and frictional melting at shallow crustal levels: the cataclasite pseudotachylyte connection. Tectonophysics 204:243-260.

Magloughlin, J. F., and Spray, J. G. 1992. Frictional melting processes and products in geological material: introduction and discussion. Tectonophysics 204:197206.

Malone, D. H.; Hauge, T. A.; and Beutner, E. C. 1999. Field guide for the Heart Mountain detachment and associated structures, northeast Absaroka Range, Wyoming. In Lageson, D. R.; Lester, A. P.; and Trudgill, B. D., eds. Colorado and adjacent areas. Geol. Soc. Am. Field Guide 1:177-201.

Masch, L.; Wenk, H. R.; and Preuss, E. 1985. Electron microscopy study of hyalomylonites: evidence for frictional melting in landslides. Tectonophysics 115:131160.

Miller, M. G. 1999. Gravitational reactivation of an extensional fault system, Badwater Turtleback, Death Valley, California. In Wright, L. A., and Troxel, B. W., eds. Cenozoic basins of the Death Valley region. Geol. Soc. Am. Spec. Pap. 333:367-376.

Moore, D. W.; Oriel, S. S.; and Mabey, D. R. 1987. A Neogene (?) gravity-slide block and associated slide phenomena in Swan Valley graben, Wyoming and Idaho. In Beus, S. S., ed. Centennial Field Guide (vol. 2): Rocky Mountain section. Boulder, CO, Geol. Soc. Am., p. 113-116.

Moores, E. M. 1968. Mio-Pliocene sediments, gravity slides, and their tectonic significance, east-central Nevada. J. Geol. 76:88-98.

Moores, E. M.; Scott, R. B.; and Lumsden, W. W. 1968. Tertiary tectonics of the White Pine-Grant Range region, east-central Nevada, and some regional implications. Geol. Soc. Am. Bull. 79:1703-1726.

Morris, T. H., and Hebertson, G. F. 1996. Large-rock avalanche deposits, eastern Basin and Range, Utah: emplacement, diagenesis, and economic potential. Am. Assoc. Pet. Geol. Bull. 80:1135-1149.

Newman, J., and Mitra, G. 1994. Fluid-influenced deformation and recrystallization of dolomite at low temperatures along a natural fault zone, Mountain City window, Tennessee. Geol. Soc. Am. Bull. 106:12671280.

Olmore, S. D. 1971. Style and evolution of thrusts in the 
region of the Mormon Mountains, Nevada. PhD dissertation, University of Utah, Salt Lake City.

Peterson, G. L. 1968. Flow structures in sandstone dikes. J. Sediment. Geol. 2:177-190.

Philip, H., and Ritz, J.-F. 1999. Gigantic paleolandslide associated with active faulting along the Bogd fault (Gobi-Altay, Mongolia). Geology 27:211-214.

Pierce, W. G. 1957. Heart Mountain and South Fork detachment thrusts of Wyoming. Am. Assoc. Pet. Geol. Bull. 41:591-626.

1979. Clastic dikes of Heart Mountain fault breccia, northwest Wyoming, and their significance. U.S. Geol. Surv. Prof. Pap. 1133:1-25.

- 1980. The Heart Mountain break-away fault, northwestern Wyoming. Geol. Soc. Am. Bull. 91:272281.

Pouliquen, O., and Vallance, J. W. 1999. Segregation induced instabilities of granular fronts. Chaos 9:621630.

Reber, S. J. 1952. Stratigraphy and structure of the Beaver Dam Mountains. Intermt. Assoc. Pet. Geol. Guidebook 7:101-108.

Rietbrock, A.; Tiberi, C.; Scherbaum, F.; and Lyon-Caen, H. 1996. Seismic slip on a low angle normal fault in the Gulf of Corinth: evidence from high-resolution cluster analysis of microearthquakes. Geophys. Res. Lett. 23:1817-1820.

Ross, C. P. 1961. Geology of the southern part of the Lemhi Range, Idaho. U.S. Geol. Surv. Bull. 1081-F: 189-260.

Schmitt, K. R. 1991. Sandstone intrusions in the Andean fold-thrust belt $\left(51^{\circ}-54^{\circ} \mathrm{S}\right)$ : implications for the paleohydrogeologic evolution of the southernmost Andes. PhD dissertation, Columbia University, New York.

Scholz, C. H. 2002. The mechanics of earthquakes and faulting (2nd ed). Cambridge, Cambridge University Press, $471 \mathrm{p}$.

Scholz, C. H.; Dawers, N. H.; Yu, J.-J.; Anders, M. H.; and Cowie, P. A. 1993. Fault growth and scaling laws: preliminary results. J. Geophys. Res. 98:21,95121,961 .

Secor, D. T., Jr. 1963. Geology of the central Spring Mountains, Nevada. PhD dissertation, Stanford University, Stanford, CA.

Shaller, P. J. 1991. Analysis and implications of large Martian and terrestrial landslides. PhD dissertation, California Institute of Technology, Pasadena.

Sibson, R. H. 1975. Generation of pseudotachylyte by ancient seismic faulting. Geophys. J. R. Astro. Soc. 43: 775-794.

- 1985. A note on fault reactivation. J. Struct. Geol. 7:751-754.

Sibson, R. H.; Robert, F.; and Poulsen, K. H. 1988. Highangle reverse faults, fluid-pressure cycling, and mesothermal gold-quartz deposits. Geology 16:551-555.

Skelly, M. F. 1987. The geology of the Moapa Peak area, southern Mormon Mountains, Clark and Lincoln Counties, Nevada. MS thesis, Northern Arizona University, Flagstaff.
Snoke, A. W.; Tullis, J.; and Todd, V. R. 1998. Fault-related rocks: a photographic atlas. Princeton, NJ, Princeton University Press, 617 p.

Streit, J. E. 1998. Multiple generations cataclasites. In Snoke, A. W.; Tullis, J.; and Todd, V. R., eds. Faultrelated rocks: a photographic atlas. Princeton, NJ, Princeton University Press, p. 54-55.

Tarasewicz, J. P. T.; Woodcock, N. H.; and Dickson, J. A. D. 2005. Carbonate dilation breccias: examples from the damage zone to the Dent Fault, northwest England. Geol. Soc. Am. Bull. 117:736-745.

Taylor, W. J. 1984. Superposition of thin-skinned normal faulting on Sevier orogenic belt thrusts, northern Mormon Mountains, Lincoln County, Nevada. MS thesis, Syracuse University, Syracuse, NY.

Templeton, A. S.; Sweeney, J.; Manske, H.; Tilghman, J. F.; Calhoun, S. C.; Violich, A.; and Chamberlain, C. P. 1995. Fluids and the Heart Mountain fault revisited. Geology 23:929-932.

Tschanz, C. M., and Pampeyan, E. H. 1970. Geology and mineral deposits of Lincoln County, Nevada. Nev. Bur. Mines Bull. 73, 188 p.

Tuttle, O. F. 1949. Structural petrology of planes of liquid inclusions. J. Geol. 57:331-356.

Vallance, J. W., and Scott, K. M. 1997. The Osceola mudflow from Mount Rainier: sedimentology and hazard implications of a huge clay-rich debris flow. Geol. Soc. Am. Bull. 109:143-163.

Vermilye, J. M., and Scholz, C. H. 1998. The process zone: a microstructural view of fault growth. J. Geophys. Res. 103:12,223-12,237.

Voight, B., and Pariseau, W. G. 1978. Rockslides and avalanches: an introduction. In Voight, B., ed. Rockslides and avalanches (vol. 1): natural phenomena. Elsevier, New York, Dev. Geotech. Eng. 14A:1-67.

Walker, C. D.; Anders, M. H.; Nagel, T.; and ChristieBlick, N. 2004. Using field evidence to distinguish between rooted and rootless detachment faults in the Mormon Mountains, southeastern Nevada. Geol. Soc. Am. Abstr. 36:548.

Wernicke, B. P. 1982. Processes of extensional tectonics. $\mathrm{PhD}$ dissertation, Massachusetts Institute of Technology, Cambridge.

. 1992. Cenozoic extensional tectonics of the U.S. Cordillera. In Burchfiel, B. C.; Lipman, P. W.; and Zoback, M. L., eds. The Cordilleran Orogen: conterminous United States (Geology of North America, Vol. G-3). Boulder, CO, Geol. Soc. Am., p. 553-581.

- 1995. Low-angle normal faults and seismicity: a review. J. Geophys. Res. 100:20,159-20,174.

Wernicke, B. P., and Axen, G. J. 1988. On the role of isostasy in the evolution of normal fault systems. Geology 16:848-851.

Wernicke, B. P.; Axen, G. J., and Snow, J. K. 1988. Basin and Range extensional tectonics at the latitude of Las Vegas. Geol. Soc. Am. Bull. 100:1738-1757.

Wernicke, B. P.; Snow, J. K.; Axen, G. J.; Burchfiel, B. C.; Hodges, K. V.; Walker, J. D.; and Guth, P. L. 1989. Extensional tectonics in the Basin and Range Province 
between the southern Sierra Nevada and the Colorado Plateau. In Hanshaw, P. M., ed. Sedimentation and tectonics of western North America. 28th Int. Geol. Congr., Vol. 3, Field Trip T138:1-80.

Wernicke, B. P.; Walker, J. D.; and Beaufait, M. S. 1985. Structural discordance between Neogene detachments and frontal Sevier thrusts, central Mormon Mountains, southern Nevada. Tectonics 4:213-246.

Wills, S., and Anders, M. H. 1999. Tertiary normal faulting in the Canyon Range, eastern Sevier Desert. J. Geol. 107:659-682.

Wojtal, S., and Mitra, G. 1986. Strain-harding and strain softening in fault zones from foreland thrusts. Geol. Soc. Am. Bull. 97:674-687.

Yarnold, J. C. 1993. Rock-avalanche characteristics in dry climates and the effect of flow into lakes: insights from mid-Tertiary sedimentary breccias near Artillery Peak, Arizona. Geol. Soc. Am. Bull. 105:345-360.

Yarnold, J. C., and Lombard, J. P. 1989. A facies model for large rock-avalanche deposits formed in dry climates. In Colburn, I. P.; Abbott, P. L.; and Minch, J., eds. Conglomerates in basin analysis: a symposium dedicated to A. O. Woodford. Soc. Econ. Paleontol. Mineral. (Pac. Sec.) 62:9-31. 